\title{
Pathogenicity, Molecular Characterization, and Cercosporin Content of Brazilian Isolates of Cercospora kikuchii
}

\author{
Álvaro M. R. Almeida ${ }^{1}$, Fernanda F. Piuga ${ }^{5}$, Silvana R. R. Marin ${ }^{1}$, Eliseu Binneck ${ }^{1}$, Fábio Sartori ${ }^{2}$, \\ Leila M. Costamilan ${ }^{3}$, Maria R. O. Teixeira ${ }^{4} \&$ Marcelo Lopes $^{6}$ \\ ${ }^{1}$ Embrapa Soja, Cx. Postal 231, CEP 86001-970, Londrina, PR, Brazil, e-mail: amra@ @npso.embrapa.br; ${ }^{2}$ Milenia \\ Biotecnologia \& Genética Ltda, Rua Pedro Antônio de Souza, 405, CEP 86031-610, Londrina,PR, Brazil, ${ }^{3}$ Embrapa \\ Trigo, Cx. Postal 451, CEP 99001-970, Passo Fundo, RS, Brazil, ${ }^{4}$ Embrapa Agropecuária Oeste, Cx. Postal 661, \\ CEP 79804-970 Dourados, MS; ${ }^{5}$ UNOPAR, Av. Paris, 675, CEP 86041-140, Londrina, PR, Brazil; ${ }^{6}$ Departamento de \\ Ciências Agrárias, Universidade de Cruz Alta, UNICRUZ, CEP 98025-810, Cruz Alta, RS, Brazil
}

(Accepted for publication 05/10/2005)

Corresponding author: Álvaro M. R. Almeida

ALMEIDA, A.M.R., PIUGA, F.F., MARIN, S.R.R., BINNECK, E., SARTORI, F., COSTAMILAN, L.M., TEIXEIRA, M.R.O. \& LOPES, M. Pathogenicity, molecular characterization, and cercosporin content of Brazilian isolates of Cercospora kikuchii. Fitopatologia Brasileira 30:594-602. 2005.

\section{ABSTRACT}

Cercospora kikuchii, involved with the defoliation of soybean (Glycine max) plants, is normally associated with Septoria glycines in late season. Seventy-two isolates from different regions in Brazil, obtained mainly from purple stained seeds, showed phenotypic variation. Cercosporin content and rate of colony growth was higly variable among isolates. A strong correlation between cercosporin content and virulence was identified. Genetic variation among and within populations was evaluated based on 86 RAPD loci. The RAPD analysis clustered all isolates into seven groups. No relationship was observed between RAPD groups and geographic origin or cercosporin content. The sequence of the internal spacer regions (ITS1-5.8S-ITS2) from 13 isolates chosen according to the previous RAPD and clustering analysis showed high similarity (97\%-100\%) to the GenBank sequences of C. kikuchii (AY266160, AY266161, AY152577 and AF291708). It is clear from this work that Brazilian isolates of $C$. kikuchii from different geographic regions, are variable in relation to virulence, RAPD profiles and cercosporin content. Cercosporin content could be a good parameter for choosing an adequate isolate for screening resistant or tolerant cultivars. Considering that this pathogen is easily seedborne, findings are expected to show the same haplotypes in different regions. Migration could be favoured by infected seeds as demonstrated by RAPD analysis.

Additional keywords: genotypic diversity, PCR-RFLP, RAPD, ITS sequence, virulence.

\section{RESUMO}

Patogenicidade, caracterização molecular e teor de cercosporina de isolados brasileiros de Cercospora kikuchii

Cercospora kikuchii está envolvido na desfolha da soja (Glycine max), normalmente em associação com Septoria glycines, no final do ciclo da cultura. Setenta e dois isolados, obtidos principalmente de sementes com mancha púrpura e oriundas de diferentes regiões do Brasil, mostraram variabilidade fenotípica. O teor de cercosporina e a velocidade de crescimento de colônias foram bastante variáveis entre os isolados. Uma forte correlação foi identificada entre o teor de cercosporina e virulência. Diferenças genéticas, entre e dentro da população analisada, foram observadas por RAPD com a análise de 86 loci. As análises de RAPD permitiram agrupar os isolados em sete grupos. Nenhuma relação foi identificada entre os grupos de RAPD e a origem geográfica ou teor de cercosporina. A sequência da região espaçadora do DNA ribossomal (ITS1-5,8S-ITS2) foi determinada em 13 isolados escolhidos nos diferentes agrupamentos. A similaridade das sequências obtidas comparadas às sequências de C. kikuchii depositadas no GenBank (AY266160, AY266262, AY152577 e AF291708) variou de 97 a 100\%. Este trabalho demonstrou que os isolados brasileiros de C. kikuchii de diferentes origens são variáveis quanto à virulência, aos padrões de RAPD e ao teor de cercosporina. O teor de cercosporina pode ser um bom parâmetro na escolha de um isolado adequado para seleção de cultivares tolerantes ou resistentes a esse patógeno. Considerando que ele é facilmente transmitido por sementes não é surpresa encontrar os mesmos haplotipos em diferentes regiões. A migração poderia ser favorecida por sementes infetadas como demonstrado na análise de RAPD.

Palavras-chave adicionais: diversidade genética, PCR-RFLP, RAPD, seqüência ITS, virulência.

\section{INTRODUCTION}

Cercospora leaf blight in soybean [Glycine max (L.) Merril] is caused by Cercospora kikuchii (Matsumoto \& Tomoyasu) M.W. Garner. It was first described in Korea then three years later in the USA (Gardner, 1925). Originally, its importance was restricted to the purple seed stain; however, Lehman (1950) observed that inoculated soybean plants in the greenhouse developed symptoms on hypocotyls, stems, leaves and petioles. Walters (1978) described defoliation in 
Pathogenicity, molecular characterization, and cercosporin content of Brazilian isolates...

soybean plants caused by $C$. kikuchii and called the disease Cercospora leaf blight. In the same report, he observed different reactions among soybean cultivars, reporting that cultivars such as Davis and Tracy were less affected than others. Currently $C$. kikuchii is associated with three symptoms on soybeans: purple seed stain, seedling death and leaf blight (Walters, 1978; Schuh, 1991).

The importance of this disease has increased in all countries where soybean is grown, especially in tropical areas (Wrather et al., 1997). In Brazil, C. kikuchii has been associated with purple seed stain (Miyasaka, 1958) for a long time. A study published by Sediyama et al. (1971) did not associate stained seeds with reduced germination; however, losses have been detected due to defoliation resulting from the development of large necrotic areas. This symptom is more prevalent in late season and is usually associated with brown spot, caused by Septoria glycines Hemmi (Almeida et al., 1997).

Although control of this disease may be achieved through genetic resistance, very little information is avaiable about the genetic variability of the pathogen. Ideally, newly bred soybean genotypes should be screened for Cercospora leaf blight prior to being released to the farmers, thus requiring that plant breeders understand the pathogen variability.

Evidence that variability occurs among isolates of $C$. kikuchii came from visual analysis of cultural and morphological characteristics on potato-dextrose-agar (PDA). Colonies originating from different regions in Brazil showed considerable phenotypic variation. The color of the mycelium among isolates ranged from white to dark olive and black. Some isolates even showed dense mycelia with slow growth in contrast to others that exhibited faster development.

In this work, the variability among C. kikuchii isolates from different areas in Brazil was analysed by RAPD, sequencing of the ITS regions of the rDNA, cercosporin content, virulence on soybean cultivars and cultural characteristics. A previous report has been published (Almeida et al., 2004).

\section{MATERIAL AND METHODS}

\section{Fungal cultures}

Seventy-two isolates of C. kikuchii from different regions of Brazil were obtained from either infected soybean seeds or leaves (Table 1). Purple stained seeds from different geographic areas were separated from soybean lots and surface sterilized in $1 \%$ sodium hypochloride for $1 \mathrm{~min}$, followed by a sterile distilled $\mathrm{H}_{2} \mathrm{O}$ wash. Blotter testing was carried out according to Neergaard (1979) for two-four days at $25{ }^{\circ} \mathrm{C}$. A small piece of the tip of the mycelium was transferred to Petri dishes containing PDA plus $1 \%$ streptomycin sulphate and incubated at $25^{\circ} \mathrm{C}$ for ten days. From the border of each uniform colony a small piece of mycelium was transferred to a new PDA dish and incubated as mentioned before. For DNA extraction, small plugs from the stock culture of each isolate were grown in $200 \mathrm{ml}$ potatodextrose broth at $26^{\circ} \mathrm{C}$ for two weeks under $18 \mathrm{~h}$ light.

\section{Mycelial growth}

One $8 \mathrm{~mm}$ diameter plug from each isolate was transferred to the center of Petri dishes with PDA, kept at 26 ${ }^{\circ} \mathrm{C}$ with $18 \mathrm{~h}$ light. The colony diameter was measured after eight, 12 and 16 days. Three plates per isolate were used.

\section{Cercosporin production assay}

Cercosporin concentration was determined spectrophotometrically according to Jenns et al. (1989). Isolates were grown on PDA and incubated at $25^{\circ} \mathrm{C}$ for six days under $18 \mathrm{~h}$ light. One mycelium plug ( $7 \mathrm{~mm}$ diameter) was cut from the border of the colonies, transferred to tubes containing $8 \mathrm{ml}$ of $5 \mathrm{~N} \mathrm{KOH}$ and kept in the dark for $4 \mathrm{~h}$. Three tubes per isolate were used. After centrifugation at $10,000 \mathrm{rpm}$ the samples were evaluated for cercosporin concentration in a spectrophotometer at $\mathrm{A}_{480} \mathrm{~nm}$ using a molar extinction coefficient of 23,300 (Jenns et al., 1989). The average volume for one plug was $0.2 \mathrm{ml}$. The experiment was repeated twice.

\section{Virulence analysis}

Inoculation was performed according to Callahan et al. (1999) with modifications: $10 \mathrm{~g}$ of mycelium scraped from a 14 day-old-colony was washed in sterilized water and homogenized in a blender with $100 \mathrm{ml}$ of sterile $0.2 \%$ water agar for $40 \mathrm{sec}$. Mycelial suspension was sprayed onto both sides of leaves from 25 day-old plants using $4 \mathrm{Kgf} / \mathrm{cm}^{2}$ pressure. After inoculation the plants were covered with plastic bags for $48 \mathrm{~h}$ and kept at a greenhouse with temperature ranging from $28-33{ }^{\circ} \mathrm{C}$. The experiment was conducted in a completely randomized block design with 20 treatments consisting of five soybean cultivars ('Davis', 'Conquista', 'Sambaíba', 'IAS-2' and 'Paraná)' inoculated with four isolates $(169,179,301$ and 444). Each replication consisted of one pot with three plants per pot, and there were three replications per treatment. Plants were rated at two and three weeks after inoculation based on diagrammatic scale adapted from James (1971). The experiment was conducted twice. The same inoculum was used to inoculate pods of the same cultivars using a syringe with $25 \times 7$ needle.

\section{DNA Extraction}

Mycelia of each of the 72 isolates were washed and centrifuged at $3,000 \times \mathrm{g}$ for $10 \mathrm{~min}$. The resulting pellets were washed in sterilized water, lightly squeezed in filter paper and stored at $-80^{\circ} \mathrm{C}$. DNA was extracted according to the method of Almeida et al. (2001b) and maintained at $-80^{\circ} \mathrm{C}$.

\section{RAPD analysis}

Seventeen random oligonucleotide (10-mer) primers (Operon Technologies, Inc., Alameda, CA, USA) were used. 
A.M.R. Almeida et al.

TABLE 1 - Soybean (Glycine max) isolates of Cercospora kikuchii obtained from purple stained seeds from different cultivars and origins in Brazil

\begin{tabular}{|c|c|c|c|c|c|}
\hline Isolate/Origin & State & Cultivar & Isolate/Origin & State & Cultivar \\
\hline 1-Londrina & PR & Embrapa 25 & 37 -Anápolis & GO & Unknown \\
\hline 2-Londrina & PR & Embrapa 133 & 38-Anápolis & GO & Unknown \\
\hline 3-Londrina & PR & Embrap a 136 & 39-Anápolis & GO & Unknown \\
\hline 4- São Carlos do Ivaí & PR & BR-37 & 40-Bagé & $\mathrm{RS}$ & Unknown \\
\hline 5-São Carlos do Ivaí & PR & BR-37 & 41-Bagé & $\mathrm{RS}$ & Unknown \\
\hline 6-Terra -Boa & PR & Ft-Abyara & 42-Bage & $\mathrm{RS}$ & Unknown \\
\hline 7-Terra -Boa & PR & BR-16 & 43-Passo-Fundo & $\mathrm{RS}$ & Unknown \\
\hline 8-Terra -Boa & PR & BR-16 & 44-Passo-Fundo & $\mathrm{RS}$ & Unknown \\
\hline 9-Santa Cecília do Pavão & PR & BR-37 & 45-Cruz-Alta & $\mathrm{RS}$ & Unknown \\
\hline 10-Santa Cecíclia do Pavão & PR & BR-37 & 46-Cruz-Alta & $\mathrm{RS}$ & Unknown \\
\hline 11 -Santa Cecília do Pavão & PR & BR-37 & 47-Cruz-Alta & $\mathrm{RS}$ & Unknown \\
\hline 12-NovaCantu & PR & Ft-Abyara & 48-Ijuí & $\mathrm{RS}$ & Unknown \\
\hline 13-Nova Cantu & PR & Unknown & 49-Ijuí & $\mathrm{RS}$ & Unknown \\
\hline 14-Nova Cantu & PR & BR-16 & 50-Londrina & PR & Clark \\
\hline 15-Peabiru & PR & BR-16 & 51-Londrina & PR & Clark \\
\hline 16-Rondonópolis & MT & Unknown & 52-Londrina & PR & Clark \\
\hline 17-Rondonópolis & MT & Unknown & 53-Londrina & PR & Cometa \\
\hline 18-Rondonópolis & MT & Unknown & 54-Londrina & PR & Cometa \\
\hline 19-Chapadão do Céu & MT & Unknown & 55-Londrina & PR & Cometa \\
\hline 20-Chapadão do Céu & MT & Unknown & 56-Imperatiz & MA & Tracajá \\
\hline 21-Chapadão do Céu & MT & Unknown & 57-Imperatriz & MA & Tracajá \\
\hline 22-Luiziana & $\mathrm{GO}$ & Unknown & 58-Imperatriz & MA & Tracajá \\
\hline 23-Luiziana & $\mathrm{GO}$ & Unknown & 59-Imperat riz & MA & Sambaíba \\
\hline 24-Luiziana & $\mathrm{GO}$ & Unknown & 60-Imperatriz & MA & Sambaíba \\
\hline 25-Mineiros & $\mathrm{GO}$ & Unknown & 61-Imperatriz & MA & Sambaíba \\
\hline 26-Mineiros & $\mathrm{GO}$ & Unknown & 62-Imperatriz & MA & Seridó \\
\hline 27-Mineiros & $\mathrm{GO}$ & Unknown & 63 -Imperatriz & MA & Seridó \\
\hline 28-Goiatuba & $\mathrm{GO}$ & Unknown & 64-Imperatriz & MA & Seridó \\
\hline 29-Goiatuba & $\mathrm{GO}$ & Unknown & 65-Francisco Beltrão & PR & FT-2000 \\
\hline 30-Goiatuba & $\mathrm{GO}$ & Unknown & 66-Francisco Beltrão & PR & FT-2000 \\
\hline 31-Rio-Verde & $\mathrm{GO}$ & Unknown & 67-Francisco Beltrão & PR & FT-2000 \\
\hline 32-Rio-Verde & $\mathrm{GO}$ & Unknown & 68-Laranjeira do Sul & PR & BR-16 \\
\hline 33-Rio-Verde & $\mathrm{GO}$ & Unknown & 69-Barreiras & BA & Unknown* \\
\hline 34-Senador Carneiro & $\mathrm{GO}$ & Unknown & 70-Londrina & PR & Unknown* \\
\hline 35-Senador Carneiro & $\mathrm{GO}$ & Unknown & 71-Sta. Cruz-Bolivia & & Unknown \\
\hline 36-Senador Carneiro & $\mathrm{GO}$ & Unknown & 72-Sta. Cruz-Bolivia & & Unknown \\
\hline
\end{tabular}

*Isolated from infected leaves with typical symptoms of Cercospora leaf blight.

Reaction mixtures were prepared for a final volume of $25 \mu \mathrm{l}$ of $10 \mathrm{mM}$ Tris- $\mathrm{HCl} \mathrm{pH} 8.3,50 \mathrm{mM} \mathrm{KCl}, 2.5 \mathrm{mM} \mathrm{MgCl} 2$, $5 \%$ Triton-X100, $10 \mathrm{mM}$ of each of the four deoxyribonucleotide triphosphates, $0.4 \mu \mathrm{M}$ primer, $25 \mathrm{U} / \mathrm{ml}$ Taq polymerase and $20 \mathrm{ng}$ of genomic DNA. Amplification was performed in a Perkin Elmer PCR system 9600 programmed for 45 cycles. Each cycle consisted of a denaturation step at $94{ }^{\circ} \mathrm{C}$ for $1 \mathrm{~min}$, a primer annealing step at $36^{\circ} \mathrm{C}$ for $1 \mathrm{~min}$, and a primer extension step at $72{ }^{\circ} \mathrm{C}$ for $2 \mathrm{~min}$. Following amplification, the products were electrophoresed on $1 \%$ agarose gel in $0.5 \mathrm{x}$ Tris-borate-EDTA (TBE) buffer $\mathrm{pH} 8.0$ for $15 \mathrm{~V} / \mathrm{cm}$, stained with ethidium bromide, and visualized by UV fluorescence.

\section{ITS RFLP analysis and sequencing}

The ITS region from 12 selected isolates, chosen according to a previous clustering analysis, was amplified with primers ITS1 (5'-TCCGTAGGTGAACCTGCGG-3') and ITS4 (5'-TCCTCCGCTTATTGATATGC-3') (White et al. (1990). Amplification reactions were performed in $50 \mu \mathrm{l}$ -volumes containing $10 \mathrm{mM}$ Tris- $\mathrm{HCl}$ (pH 8.3), $50 \mathrm{mM} \mathrm{KCl}$, $2.5 \mathrm{mM} \mathrm{MgCl}, 200 \mu \mathrm{M}$ each deoxynucleoside triphosphate, $0.5 \mu \mathrm{M}$ each primer, $10 \mathrm{ng}$ of genomic DNA and $2.5 \mathrm{U}$ Taq DNA polymerase. Temperature parameters were $94{ }^{\circ} \mathrm{C}$ for DNA denaturation, $3 \mathrm{~min}$ for the first cycle and $1 \mathrm{~min}$ for the remaining cycles, $45^{\circ} \mathrm{C}$ for $1 \mathrm{~min}$ for primer annealing, and $72{ }^{\circ} \mathrm{C}$ for $2 \mathrm{~min}$ for primer extension with a total of 35 cycles. Amplified products were analyzed by electrophoresis in $1.2 \%$ agarose gel and visualized after staining with ethidium bromide. A sample of $20 \mu \mathrm{l}$ of each PCR product was digested with RsaI, Eco RV, Dra I, Eco RI, Hae III, Mse I, Pst I, Taq I, according to the manufacturer's instructions. Digested DNA was run on $2 \%$ agarose gels. The gels were stained with ethidium bromide $(0.5 \mu \mathrm{g} / \mathrm{ml})$, and DNA was visualized under UV light.

Sequencing was performed by the chain-termination 
Pathogenicity, molecular characterization, and cercosporin content of Brazilian isolates...

method using the ABI Big Dye Terminator Cycle sequencing kit v 2.0 (Applied Biosystems Inc., Foster City, CA, USA) on an ABI PRISM model 3100 DNA sequencer.

\section{Analysis of genetic similarity}

The RAPD bands and restriction fragments were scored as present (1) or absent (0). Data were analyzed using the numerical taxonomy package NTSYSpc version 2.02.j. A similarity matrix was produced with the SIMQUAL program using the Nei \& Li (1979) distance coefficient which measures the proportion of band mismatches between pairs of isolates. Cluster analysis was performed with the cluster program SAHN using the unweighted pair-group method with arithmetic averages (UPGMA). Principal coordinate analysis was obtained using the eigen values and eigen vectors for real symmetric matrices inside the ordination subroutine. Bootstrap analysis was obtained by 1000 replications with the program WINBOOT (Yap \& Nelson, 1996).

\section{Analysis of molecular variance}

Analysis of molecular variance (AMOVA) was performed using WINAMOVA (Excoffier et al. 1992) on $C$. kikuchii isolates to partition the total variance into that attributable to differences within and among populations components and among populations within groups (states). Isolates from one specific state constituted a population. For this analysis a total of 19 populations were considered (Londrina, São Carlos do Ivaí, Francisco Beltrão, Terra Boa, Santa Cecília do Pavão, Nova Cantú, Rondonópolis, Chapadão do Sul, Luiziana, Mineiros, Goiatuba, Rio Verde, Senador Carneiro, Anápolis, Bagé, Passo Fundo, Cruz Alta, Ijuí and Imperatriz) and together with 70 isolates from the states of PR, MT, GO, RS and MA.Two isolates from Bolivia were not included because of the low number. The variance among populations and the F statistic were tested by nonparametric randomization analysis. Estimation for gene flow (Nm) among populations and among states was performed using POPGENE, version 1.31; (http:// www.ualberta.ca/ fyeh/).

\section{RESULTS}

\section{Cultural characteristics, cercosporin content and mycelial growth}

Seventy-two C. kikuchii isolates from the most diverse soybean growing regions were observed for variation in the color of the mycelium and their morphology. Most colonies (51) had a purple tinge when observed from the underside of the Petri dish. Some colonies (21), however, were white to light gray or black. The mycelia on top varied greatly between white or dark gray to light violet. Since isolates exhibited different growth rates on PDA, seven randomly chosen isolates (1, 28, 31, 47, 63, 68 and, 75) were followed during a 16 day-period to estimate daily growth rate. Isolates 31 and 28 exhibited the fastest growth $(0.71 \mathrm{~cm} /$ day $)$ and slowest growth rate $(0.29 \mathrm{~cm} /$ day $)$, respectively.
The concentration of cercosporin was variable among isolates and among replications ranging from 0.3 to $41 \mathrm{nmol} /$ $\mathrm{ml}$ for isolates 37 and 47 , respectively.

\section{Virulence analysis}

Virulence analysis performed with four isolates with different capacities for cercosporin synthesis showed that all isolates were able to infect soybean leaves, and that there was a correlation coefficient of $83 \%$ between cercosporin content and disease severity (Table 2). Isolates that showed purple to red halos in PDA media were also those that produced more cercosporin and were the most virulent. Lesions had a central necrotic area with a yellow halo visible one to two weeks after inoculation. Symptoms began to appear four to seven days after inoculation as irregular spots. Yellow halos developed three to seven days after the formation of the necrotic lesions. Isolates that produced low levels of cercosporin caused very small number of tiny necrotic foliar lesions. When inoculated into pods they were also able to induce purple seed stain (data not shown).

\section{Analysis of genetic similarity}

Of the 17 primers screened, 14 produced reproducible RAPD fragments in two trials. A total of 86 selected polymorphic amplicons were detected and generated a matrix of genetic distance. A dendrogram with seven clusters was obtained through the UPGMA (Figure 1). The matrix of similarities generated with all 72 isolates showed genetic distances ranging from $33 \%$ to $99 \%$. The first cluster was comprised of 13 isolates with similarities ranging from $73 \%$ to $79 \%$, with an average of $77 \%$. The second cluster contained the majority of the isolates (51) for similarities ranging from $73 \%$ to $88 \%$, for an average of $85 \%$. The third cluster was formed by two isolates with similarities of $76 \%$. The fourth cluster contained three isolates with similarities of $72 \%$ to $84 \%$ and an average of $79 \%$. The fifth, sixth and seventh clusters contained only one isolate each. The geographic origin and virulence of the isolates did not correlate with RAPD groups. No marker was specific to an isolate's ability to produce cercosporin.

Bootstrap analysis of the 1,000 interactions showed values ranging from $53 \%$ to $100 \%$. Principal coordinates analysis confirmed the clustering of isolates into seven groups with $79 \%$ of total variance explained by the two vectors used (Figure 2).

\section{Analysis of molecular variance}

Genetic differentiation among and within populations was observed based on 86 RAPD loci. The AMOVA analysis within population and the coefficient of genetic differentiation among populations are shown in Table 3 . The "among States" effect explained 2.64\% of the total variance. Within populations and among populations represented $75.09 \%$ and $22.27 \%$ of the total variance, respectively (Table 3 ), suggesting that the majority of genetic diversity was found within populations. Gene flow $\left(\mathrm{N}_{\mathrm{m}}\right)$ among 
A.M.R. Almeida et al.

TABLE 2 - Virulence analysis of Cercospora kikuchii isolates showing different cercosporin concentrations in soybean (Glycine max) cultivar

\begin{tabular}{|c|c|c|c|c|c|}
\hline \multirow{2}{*}{ Soybean Cultivar } & \multicolumn{4}{|c|}{ Isolate (Cercosporin content) } & \multirow{2}{*}{ Average } \\
\hline & $12\left(6.1^{*}\right)$ & $3(12.5)$ & $20(16.1)$ & $63(33.0)$ & \\
\hline IAS-2 & $1.00 \mathrm{~B} * *$ & $1.67 \mathrm{~B} * *$ & $2.00 \mathrm{~B}^{* *}$ & $2.57 \mathrm{~B} * *$ & $1.83 \mathrm{~B}^{* *}$ \\
\hline Davis & $1.67 \mathrm{AB}$ & $3.33 \mathrm{~A}$ & $3.00 \mathrm{~A}$ & $4.67 \mathrm{~A}$ & $3.16 \mathrm{~A}$ \\
\hline Sambaíba & $1.67 \mathrm{AB}$ & $3.67 \mathrm{~A}$ & $3.67 \mathrm{~A}$ & $5.33 \mathrm{~A}$ & $3.58 \mathrm{~A}$ \\
\hline Paraná & $1.67 \mathrm{AB}$ & $2.67 \mathrm{~A}$ & $3.00 \mathrm{~A}$ & $5.00 \mathrm{~A}$ & $3.08 \mathrm{~A}$ \\
\hline Conquista & $2.00 \mathrm{~A}$ & $3.00 \mathrm{~A}$ & $3.67 \mathrm{~A}$ & $5.33 \mathrm{~A}$ & $3.50 \mathrm{~A}$ \\
\hline Average & $1.60 \mathrm{c}$ & $2.87 \mathrm{~b}$ & $3.07 \mathrm{~b}$ & $4.60 \mathrm{a}$ & \\
\hline
\end{tabular}

* Cercosporin content (nmol/ml) measured according to Jens et al. 1989

$* * 1=0 \%-1 \%$ infected leaf area; $2=2 \%-5 \%$ infected leaf area; $3=6 \%-10 \%$ infected leaf area; $4=11 \%-25 \%$ infected leaf area; $5=26 \%$ $50 \%$ infected leaf area; $6=51 \%-75 \%$ infected leaf area; $7=>75 \%$ infected leaf area (adapted from James, 1971). Values followed by the same capital letter within a column and small letters in a line are not significantly different at $\mathrm{P}<0.05$ according to Tukey's test. No. of sampled leaves $=8$.

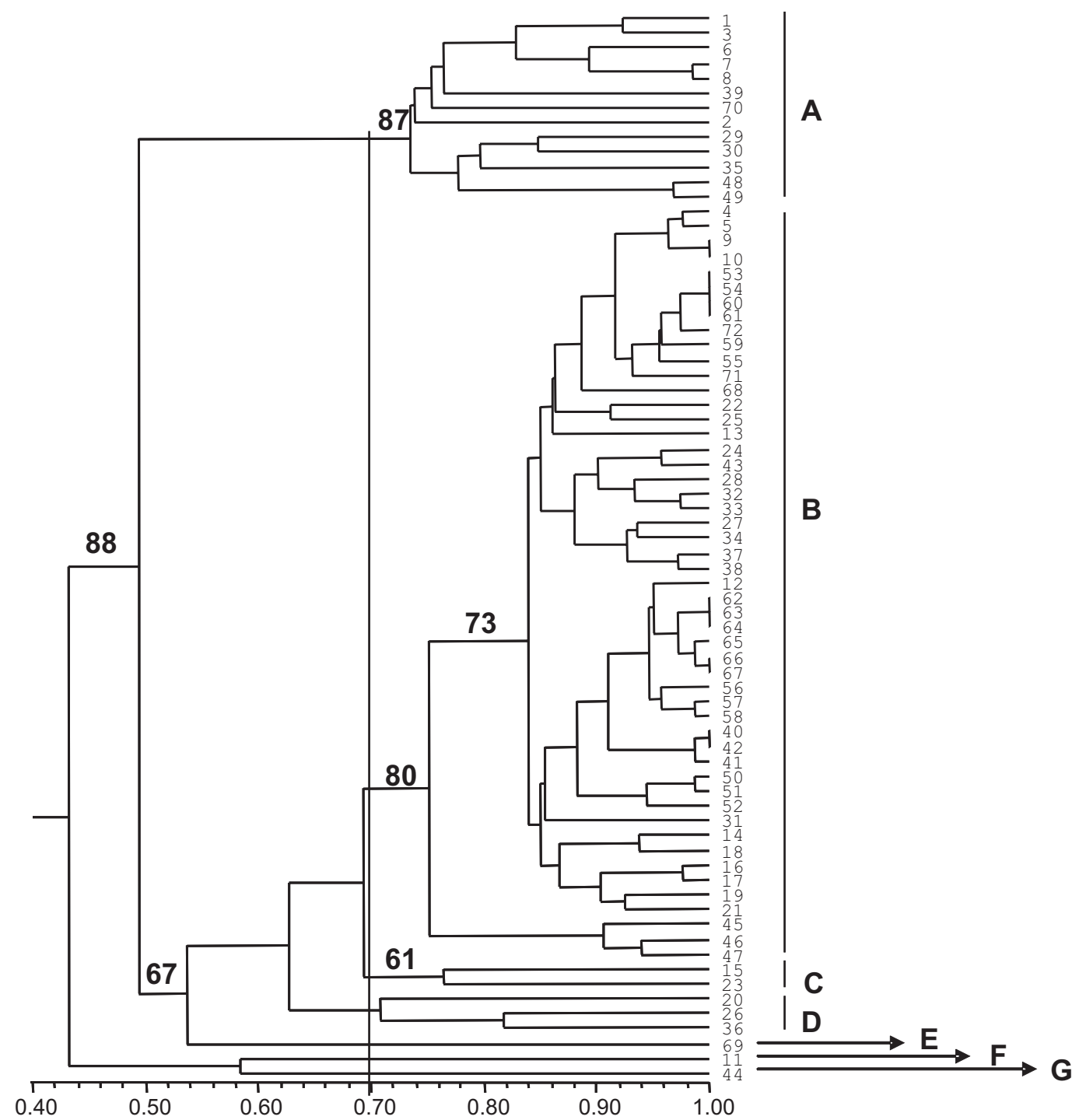

FIG. 1 - Genetic similarity among 72 Cercospora kikuchii isolates sampled from different regions in Brazil. Phenogram was estimated by clustering a distance matrix (Dice coefficient) of binary random amplified polymorphic DNA data using the unweighted pair group method of arithmetic means in the NTSYS program. Numbers at the major branches indicate the percentage occurrence of the cluster to the right of the branch in 1,000 bootstrapped data sets. Only branches occurring in 50\% or more of the bootstrapped phenograms are labeled. A to $\mathrm{G}$ indicate the seven clusters of isolates found. 

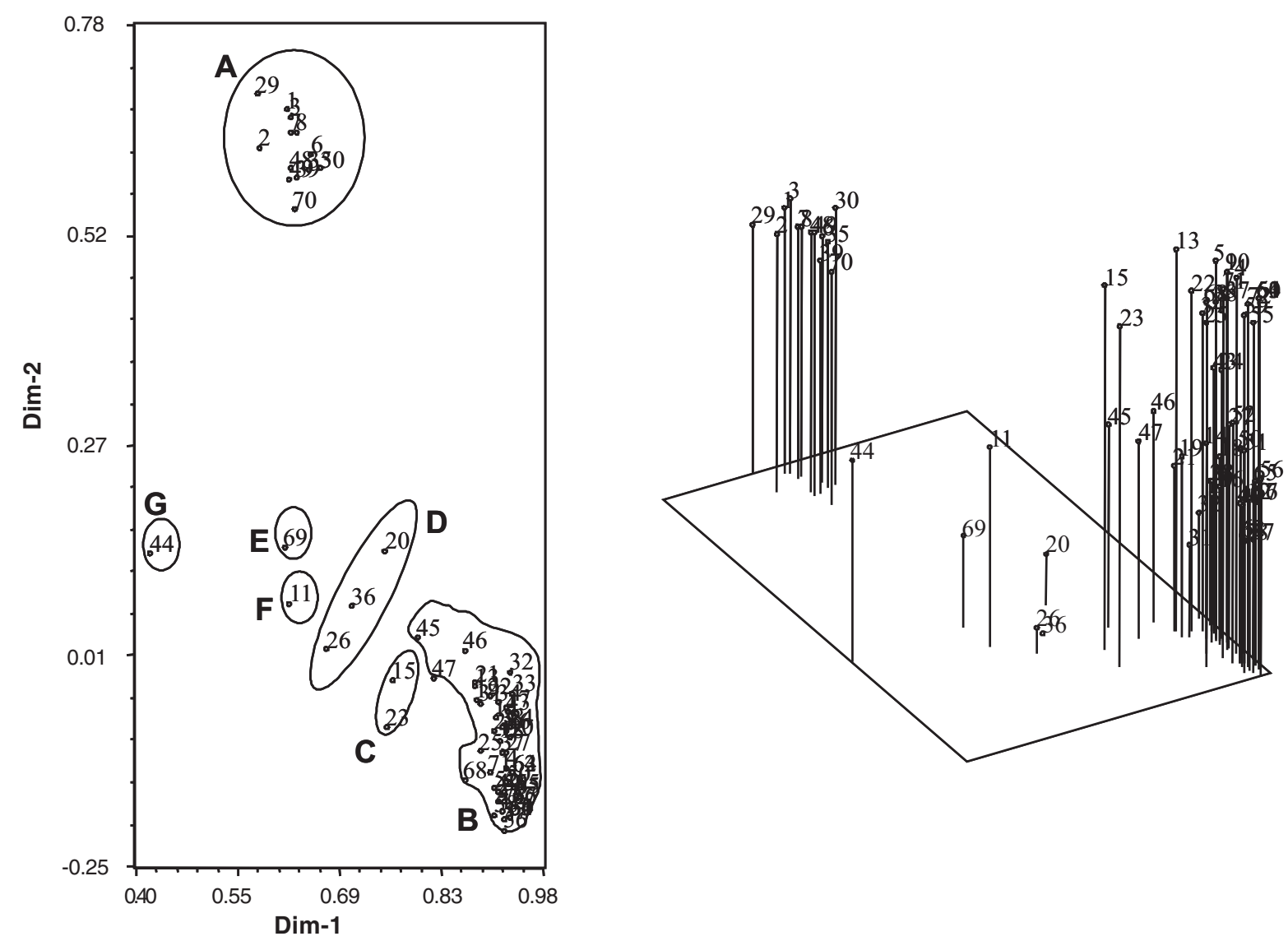

FIG. 2 - Two and three dimensional principal coordinate analysis of 72 Cercospora kikuchii isolates grouped in seven clusters (A through G). X and Y-axes account for $79 \%$ of total variation observed. X, Y and Z-axes account for $82.5 \%$ of total variance observed.

populations over all loci (0.45) was smaller than among States that showed $\mathrm{N}_{\mathrm{m}}$ of 1.33 .

\section{ITS-RFLP and sequencing}

PCR with primers ITS1 and ITS4 produced a DNA fragment of approximately $560 \mathrm{bp}$ for the 12 isolates tested. No size variation was found among the amplified ITS regions. Of eight restriction enzymes used only three (Nde II, Hinf I and $A l u \mathrm{I})$ cut the fragment. The observed band sizes were 310 and 200 bp for Nde II, 300 and 210 bp for Hinf I and, 380 and $140 \mathrm{bp}$ for Alu I. No polymorphism was detected among the samples. Cercospora sojina Hara was used as an out group and it exhibited a band of approximately $600 \mathrm{bp}$ with the same number of restriction sites as $C$. kikuchii but producing fragments of different sizes (for example $400 \mathrm{bp}$ and 150 bp with Rs).

The PCR-amplified and cloned sequences of the 5.8 rDNA gene and its ITS flanking regions from all the 12 isolates were aligned. Sequences demonstrated identity of $97 \%$ to $100 \%$ with four sequences of C. kikuchii (GenBank accession no. AY266160, AY266161, AY152577 and AF291708). The comparison of Brazilian sequences (12) with

TABLE 3 - Analysis of molecular variance at three-levels for populations of Cercospora kikuchii, using random amplified polymorphic DNA phenotypes*

\begin{tabular}{lccccc}
\hline \hline Source & df & Variance & Total variance (\%) & Ф statistic & $\boldsymbol{p}$ \\
\hline Among States & 5 & 0.3066 & 2.64 & & \\
W ithin populations & 51 & 8.7133 & 75.09 & 0.249 & 0.001 \\
Among populations and within States & 14 & 2.5846 & 22.27 & & \\
\hline
\end{tabular}

*Probability of having an equal or more extreme variance component statistic than the observed values by chance alone. Tested by nonparametric randomization analysis, using 1,000 repetitions. 
these four C. kikuchii sequences from the GenBank showed the values ranging from 0 to $6 \mathrm{nts}$ differences. The overall mean number of differences among Brazilian isolates was $1.2 \mathrm{nts}$ over all 12 pair-wise comparisons. Most of the differences were inside the ITS2. The numbers of transitions within each of the 12 sequences from Brazilian isolates ranged from 0 to 3 while no transversions were observed. In another comparison, using the same 12 sequences with an isolate of $C$. sojina (GenBank AY266158) the values ranged from 2 to 5 nts (Table 4).

\section{DISCUSSION}

The objective of this work was to investigate phenotypic and genotypic variation among isolates of $C$. kikuchii in order to provide information for the soybean breeding program at Embrapa Soja. Data from this study revealed a considerable degree of variation in the population of $C$. kikuchii confirming previous results obtained by Almeida et al. (2001a) who had observed differences in morphological types and levels of pigmentation of the media where the isolates were grown.

Red pigmentation around colonies was caused by cercosporin, a non-host-specific phytotoxin isolated in 1957 (Kuyama \& Tamura, 1957) from C. kikuchii. The role of cercosporin in the pathogenicity of $C$. kikuchii was first demonstrated by Upchurch et al. (1991) who considered it crucial for the infection of soybean plants. They observed that spontaneous and UV-induced mutants that did not produce cercosporin were not able to cause infection when inoculated on soybean leaves. In our study the differences in virulence among the isolates were associated with cercosporin content, and constitute unprecedented information for this pathosystem. Cercosporin when excited by light produces hydroxyl radicals and singlet oxygen. Singlet oxygen catalyses peroxidation of lipid membrane, disrupting cellular integrity, inducing leakage of cytoplasmic contents and causing cell death (Daub \& Ehrenshaft, 2000).

The observation of red color around the colony appeared valueless in predicting virulence, since several isolates with no reddish color were virulent. However, all isolates with pigmented colonies were the most virulent. Isolates that produced more cercosporin were also more virulent.

It was not clear in our studies if the lack of color in the extract for colorimetric assay observed in some isolates could be due to the sensitivity of the method used since isolates with very low amounts of cercosporin were also able to cause lesions when inoculated on soybean leaves or purple stained seeds when inoculated into pods. Cercosporin content varied considerably among replications from the same colony and from different colonies.

The RAPD has been successfully used to assess the genetic variability of Cercospora species (Inglis et al., 2001; Weiland et al., 2001). The genetic diversity observed among isolates through RAPD analysis was also an important result from this work. Seven RAPD groups were present among 72 isolates studied; however, the groups could not be correlated with cercosporin content, virulence or geographic origin of the isolates.

Similarly to other studies (Goodwin et al., 2001; Almeida et al., 2001b) molecular techniques such as RAPD provided strong evidence of genetic diversity among fungi. Under our conditions and for the proposed objectives these proved reliable and of low cost in relation to other methods.

There was no association between the groups of isolates, based on RAPD markers and cercosporin content. Isolates that produced high contents of cercosporin were

TABLE 4 - Pair-wise comparison between number of nucleotide differences of internal transcribed spacer regions of the ribosomal genes from Brazilian Cercospora kikuchii isolates (6 through 17) and C. sojina (AY266158) and C. kikuchii (AY266160, AY266161, AY152577 and AF291708) from GenBank

\begin{tabular}{|c|c|c|c|c|c|c|c|c|c|c|c|c|c|c|c|c|c|}
\hline & [1] & {$[2]$} & [3] & {$[4]$} & [5] & {$[6]$} & [7] & {$[8]$} & [9] & {$[10]$} & [11] & {$[12]$} & [13] & {$[14]$} & {$[15]$} & [16] & {$[17]$} \\
\hline \multicolumn{18}{|c|}{ (2) } \\
\hline [2]AY152577 & 4 & & & & & & & & & & & & & & & & \\
\hline [3]AY266161 & 6 & 2 & & & & & & & & & & & & & & & \\
\hline [4]AY266160 & 4 & 0 & 2 & & & & & & & & & & & & & & \\
\hline [5]AY266158 & 8 & 4 & 4 & 4 & & & & & & & & & & & & & \\
\hline [6]AY6 33835 & 5 & 1 & 1 & 1 & 5 & & & & & & & & & & & & \\
\hline [7]AY633836 & 6 & 2 & 2 & 2 & 4 & 3 & & & & & & & & & & & \\
\hline [8]AY633837 & 5 & 1 & 1 & 1 & 5 & 0 & 3 & & & & & & & & & & \\
\hline [9]AY633838 & 5 & 0 & 2 & 0 & 4 & 1 & 2 & 1 & & & & & & & & & \\
\hline [10]AY633839 & 5 & 1 & 1 & 1 & 5 & 0 & 3 & 0 & 1 & & & & & & & & \\
\hline [11]AY633840 & 5 & 1 & 1 & 1 & 3 & 0 & 3 & 0 & 1 & 0 & & & & & & & \\
\hline [12]AY633844 & 5 & 1 & 1 & 1 & 5 & 0 & 3 & 0 & 1 & 0 & 0 & & & & & & \\
\hline [13]AY633841 & 5 & 1 & 3 & 1 & 5 & 2 & 3 & 2 & 1 & 2 & 2 & 2 & & & & & \\
\hline [14]AY633842 & 4 & 0 & 2 & 0 & 4 & 1 & 2 & 1 & 0 & 1 & 1 & 1 & 1 & & & & \\
\hline [15]AY739106 & 5 & 1 & 1 & 1 & 2 & 2 & 1 & 2 & 1 & 2 & 2 & 2 & 2 & 1 & & & \\
\hline [16]AY633843 & 4 & 0 & 2 & 0 & 4 & 1 & 2 & 1 & 0 & 1 & 1 & 1 & 1 & 0 & 1 & & \\
\hline [17]AY739107 & 5 & 1 & 1 & 1 & 3 & 2 & 1 & 2 & 1 & 2 & 2 & 2 & 2 & 1 & 0 & 1 & 1 \\
\hline
\end{tabular}


clustered together with low cercosporin producers. For example, isolates $3(12.5 \mathrm{nmol} / \mathrm{ml})$ and $63(33.0 \mathrm{nmol} / \mathrm{ml})$ were high producers of cercosporin and were separated in clusters A and B, respectively. Isolates $27(11.4 \mathrm{nmol} / \mathrm{ml})$ and $37(0.3 \mathrm{nmol} / \mathrm{ml})$ were clustered together but cercosporin content was significantly higher in isolate 27.

The effect of plant genotype on the genetic diversity of the isolates used was not consistent, probably due to the low number of isolates from each cultivar. This theory is currently under investigation. Most of the isolates, despite being isolated from different soybean genotypes, clustered together.

The occurrence of different haplotypes (RAPD profiles) in the same region suggests that the pathogen populations are not genetically uniform across the area, and this work may indicate how rapidly this pathogen evolved in different environments, since isolates collected from seeds were produced in both tropical and sub-tropical Brazilian regions.

Isolates that formed a single cluster $(\mathrm{E}, \mathrm{F}$ and $\mathrm{G})$ as well as other isolates from clusters A and B were selected for ITS sequence analysis. The results showed high similarity (97\%-100\%) with published sequences of C. kikuchii (GenBank AY266160, AY266161, AY 152577 and AF291708). The number of nucleotide differences of ITS of the rDNA among all 12 sequences observed in this work ranged from 0 to 3 , with an average of 1.2 nts. However, Goodwin et al. (2001), in a previous publication, mentioned that the mean number of nucleotide differences between three isolates of C. kikuchii ranged from 2 to 7 with an average of 4.7. These differences may be due to different sets of sequences (TREEBASE) used by Goodwin et al. (2001) for comparing their isolates.

An additional comparison of Brazilian isolates (12) with an isolate of $C$. sojina (GenBank AY266158) showed values ranging from 2 to $5 \mathrm{nts}$, different from the values of Goodwin et al. (2001) that found larger values ranging from 4 to 9 nts.

The variability found in this work was confirmed through additional statistical analysis. The estimator $\ddot{\mathbf{O}}_{\text {st }}$ is highly different from zero $(\mathrm{P}>0.001)$, indicating large genetic differentiation among populations from different regions (Hartl \& Clark, 1997). The majority part of genetic variance was found within populations. The AMOVA analysis showed that the smallest fraction of variance was observed among populations within states that demonstrated substantial gene flow among states. When all isolates were analysed without clustering into states, a low estimated of genetic flow $(\mathrm{Nm}=0.45)$ was observed, suggesting that the variability among states is smaller than among collecting sites. This fact could be explained by the flux of seeds from traditional areas in the South to new areas in the Central and northern regions of Brazil. Traditional areas where soybean was cultivated for more than 30 years could have induced more diversity than new areas especially because of the genetic background of cultivars used over the years.
Populations of C. kikuchii are pathogenically, genotypically and geographically variable. Considering that this pathogen is easily transmitted by seeds it is not surprising to find the same haplotypes in different regions. Migration could be favoured by infected seeds as demonstrated by the clustering analysis.

In Brazil, there has been a rapid increase in soybean producing area since 1970; therefore, the traffic of seeds from traditional areas to new areas could be responsible for the geographical variability since C. kikuchii is a seed borne pathogen. However, this fact alone cannot explain all the genetic diversity observed. To what extent the soybean genotype may favor the development of new genetically distinct isolates is unknown. Unfortunately, an isufficient number of isolates was obtained from each area to permit the evaluation of gene flow among populations more precisely.

For a pathogen without known sexual reproduction, the observed diversity can be explained by single mutations and chromosomal aberrations like deletions, transpositions and chromosomal losses (Kistler \& Miao, 1992). According to Kempken \& Kuck (1998) transposons may increase variability in fungi. Also, fusion between vegetative cells of fungi may form heterokaryons (Carlile, 1986).

Control of Cercospora leaf blight may be possible through resistant cultivars although no resistant gene has been identified so far. However, different levels of susceptibility as observed by Walters (1978) were found in this study. These differences occurred with all isolates tested. Identification of a resistant gene against $C$. kikuchii would be a great contribution for breeding programs. However, the pathogen's variability must be considered in order to avoid drawbacks with the release of new cultivars. For countries with large soybean areas like Brazil it is very important to know in advance the variability of the pathogen, in order to avoid resistant released cultivars becoming susceptible when sown in different areas. The level of variability among isolates as identified in this work may help to define the breeding method for effective resistance.

\section{ACKNOWLEDGMENTS}

We thank Dr. E.S. Calvo and Dr. A.L. Nepomuceno for providing conditions for sequencing; L.C. Benato, M.C. Pinto and N. Valentin for helping in several steps of this work; M. Meyer and M.F. Gastal for providing infected seeds and, Dr. John Rupe (Univ. of Arkansas, USA), Dr. Marisa A. S. V. Ferreira (UnB), Dr. M. C. Bassoi and J.F. Ferraz de Toledo for discussions and suggestions on the manuscript.

Approved by the Head of Research and Development of Embrapa Soja as manuscript 141/2003.

\section{LITERATURE CITED}

ALMEIDA, A.M.R., MARIN, S.R.R., BINNECK, E., PIUGA, F.F., SARTORI, F., COSTAMILAN, L.M., TEIXEIRA, M.R. \& LOPES, 
M. Pathogenicity, molecular analysis and cercosporin content of Brazilian isolates of Cercospora kikuchii. Abstracts of the VII World Soybean Research Conference, Foz do Iguaçu. 2004. pp.69-70.

ALMEIDA, A.M.R., SARTORI, F., CALVO, E.S., MARIN, S.R.R. \& FUKUJI, T.S. Diferenciação morfo-bio-molecular de isolados de Cercospora kikuchii obtidos de sementes de soja, no Brasil. Fitopatologia Brasileira 26:328. 2001a.

ALMEIDA, A.M.R., ABDELNOOR, R.V., CALVO, E.S., TESSMAN, D. \& YORINORI, J.T. Genotypic diversity among brazilian isolates of Sclerotium rolfsii. Journal of Phytopathology 149:493-502. 2001b.

ALMEIDA, A.M.R., FERREIRA, L.P., HENNING, A.A., VELOSO, J.F.S. \& YORINORI, J.T. Doenças da Soja. In: Kimati, H., Amorin, L., Bergamin Filho, A. Camargo, L.E.A. \& Rezende, J.A.M. (Eds.). Manual de Fitopatologia. São Paulo. Ceres. 1997. pp.642-664.

CALLAHAN, T.M., ROSE, M.S., MEADE, M.J., EHRENSHAFT, M. \& UPCHURCH, G.G. CFP, the putative cercosporin transporter of Cercospora kikuchii, is required for wild type cercosporin production, resistance, and virulence on soybean. Molecular PlantMicrobe Interactions 12:901-910. 1999.

CARLILE, M.J. Genetic Exchange and Gene Flow:Their Promotion and Prevention. In: Rayner, A.D.M. \& Moore, D. (Eds.). Evolutionary Biological of the Fungi. Cambridge. Cambridge University Press. 1986. pp.203-214.

DAUB, M.E. \& EHRENSHAFT, M. The photoactivated Cercospora toxin cercosporin:contribution to plant diseases and fundamental biology. Annual Review of Phytopathology 38:461490. 2000.

EXCOFFIER, L., SMOUSE, P.E. \& QUATTRO, J.M. Analysis of molecular variance inferred from metric distances among DNA haplotypes: application to human mitochondrial DNA restriction data. Genetics 131:479-491. 1992.

GARDNER, M.W. Indiana plant diseases. Proceedings of the Indiana Academy of Science. 35:237-257. 1925.

GOODWIN, S.B., DUNKLE, L.D. \& ZISMANN, V.L. Phylogenetic analysis of Cercospora and Mycosphaerella based on the internal transcribed spacer region of ribosomal DNA. Phytopathology 91:648-658. 2001.

HARTL, D.L. \& CLARK, A.G. Principles of Population Genetics. 3.ed. Sunderland (MA):Sinauer Associates. 1997. pp.111-122.

INGLIS, P.W., TEIXEIRA, E.A., RIBEIRO, D.M., VALADARESINGLIS, M.C., TIGANO, M.S. \& MELLO, S.C.M. Molecular markers for the characterization of brazilian Cercospora caricis isolates. Current Microbiology 42:194-198. 2001.

JAMES, W.C. A manual of disease assessment keys for plant diseases. Canadian Department of Agriculture. Publication No. 1458. 1971

JENNS, A.E., DAUB, M.E. \& UPCHURCH, R.G. Regulation of cercosporin accumulation in culture by medium and temperature manipulation. Phytopathology 79:213-219. 1989.

KEMPKEN, F. \& KUCK, U. Transposons in filamentous fungi: facts and perspectives. BioEssays 20:652-659. 1998.

KISTLER, H.C. \& MIAO, V.P.W. New modes of genetic change in filamentous fungi. Annual Review of Phytopathology 30:131152. 1992.

KUYAMA, S. \& TAMURA, I. Cercosporin. A pigment of Cercospora kikuchii Matsumoto et Tomoyasu.II. Cultivation of fungus, isolation and purification of pigment. Journal of the American Chemistry Society 79:5725-5726. 1957.

LEHMAN, S.G. Purple stain of soybean seeds. North Carolina Agriculture Experimental Station Bulletin 369:1-11. 1950.

MIYASAKA, S. Contribuição para o Melhoramento da Soja no Estado de São Paulo. (Tese de mestrado) Piracicaba, ESALQ. 1958.

NEEGAARD, P. Seed Pathology. London. MacMillan.1979.

NEI, M. \& LI, H. Mathematical model for studying genetic variation in terms of restriction endonucleases. Proceedings National Academy of Science USA 76:5269-5273. 1979.

$\mathrm{SCHUH}, \mathrm{W}$. Influence of temperature and leaf wetness period on conidial germination in vitro and infection of Cercospora kikuchii on soybean. Phytopathology 81:1315-1318. 1991.

SEDIYAMA, T., CARDOSO, A.A. \& ALMEIDA, A.M.R. Estudo do comportamento de variedades e linhagens de soja. Seiva 31:257266. 1971.

UPCHURCH, R.G., WALKER, J.A., ROLLINS, J.A., EHRENSHAFT, M. \& DAUB, M.E. Mutants of Cercospora kikuchii altered in cercosporin synthesis and pathogenicity. Applied and Environmental Microbiology 57:2940-2945. 1991.

WALTERS, H.J. Cercospora leaf blight of soybeans. Phytopathology News 12:165-166. 1978.

WEILAND, J., EIDE, J., RIVERA-VARAS, V. \& SECOR, G. Genetic diversity of Cercospora beticola in the U.S. and association of molecular markers with tolerance to the fungicide triphentylin hydroxide. Phytopathology 91:S94. 2001. (Abstract) WHITE, T.J., BRUNS, T., LEE, S. \& TAYLOR, J. Amplification and Direct Sequencing of Fungal Ribosomal RNA Genes for Phylogenetics. In: Innis, M.A., Gelfand, D.H. Sninsky, White, T.J. (Eds.). PCR Protocol, a guide to methods and applications. San Diego, CA. Academic Press. 1990. pp.315-322.

WRATHER, J.A., ANDERSON, T.R., ARSYAD, D.M., GAI, J., PLOPER, L.D., PORTA-PUGLIA, A. \& RAM, H.H. Soybean disease loss estimates for the top 10 soybean producing countries in 1994. Plant Disease 81:107-110. 1997.

YAP, I. \& NELSON, R.J. Winboot:a program for performing bootstrap analysis of binary data to determine the confidence limits of UPGMA-based dendrograms. International Rice Research Institute, Manila, Philippines. International Rice Research Institute Research Paper No. 14. 1996. 